\title{
Šest godina terapijske hipotermije Six years of therapeutic hypothermia
in a cardiology intensive care unit
} u jedinici intenzivnog liječenja kardioloških bolesnika

\section{Vedran Velagić*, Željko Baričević, Maja Čikeš, Jure Samardžić, Boško Skorić, Davor Miličić}

Medicinski fakultet Sveučilišta u Zagrebu, Klinički bolnički centar Zagreb, Zagreb, Hrvatska University of Zagreb School of Medicine, University Hospital Centre Zagreb, Zagreb, Croatia

RECEIVED:

September 29, 2014

KLJUČNE RIJEČI: kardiorespiratorni arest, terapijska hipotermija, neurološki oporavak. KEYWORDS: cardiorespiratory arrest, therapeutic hypothermia, neurological recovery.

CITATION: Cardiol Croat. 2014;9(9-10):330.

*ADDRESS FOR CORRESPONDENCE: Klinički bolnički centar Zagreb, Kišpatićeva 12, HR-10000 Zagreb, Croatia. Phone: +385-91-7929-284 / E-mail: vvelagic@gmail.com

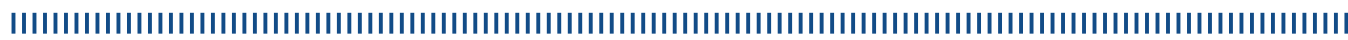

UVOD: Prije 12 godina izašle su 2 manje studije o korištenju terapijske hipotermije (TH) na temelju čega su izdane smjernice koje potiču primjenu navedene metode. ${ }^{1}$ Nedavno objavljena randomizirana studija dovodi u pitanje cijeli koncept hipotermije. ${ }^{2}$

PACIJENTI I METODE: Od 2008. godine ukupno je 38 bolesnika (14 žena, 24 muškaraca) srednje dobi 56 godina (19-80) bilo podobno za TH. Radi se o bolesnicima koji su preživjeli kardiorespiratorni arest nakon čega su ostali u komi. Cilj TH je kroz 24 sata pothladiti bolesnike na 32-34 ${ }^{\circ} \mathrm{C}$ u svrhu poboljšavanja preživljenja i neuroloških (NRL) ishoda. Svim bolesnicima je periarestno učinjena kompjutorizirana tomografija mozga i ehokardiografski pregled, a većini i koronarografija. Svi su bolesnici mehanički ventilirani i miorelaksirani te je invazivno monitoriran arterijski i centralni venski tlak, centralna temperatura, uz standardne protokole praćenja laboratorijskih krvnih parametara. TH postizana je hladnim paketima i infuzijama hladne fiziološke otopine, lavažama želuca, a od nedavno i uređajem za ekstrakorporealnu membransku oksigenaciju i posebnim centralnim venskim kateterima.

REZULTATI: Ukupno preživljenje u našoj skupini iznosi $47 \%$, od toga je $42 \%$ bolesnika imalo potpuni neurološki oporavak. Inicijalni zbir Glasgowske ljestvice za komu bolesnika iznosti 3,3 (3-7). Akutni koronarni sindrom bio je uzrok aresta u $68 \%$ bolenika dok su u ostalih prevladavale kardiomiopatije. Izvanbolnički arest doživjelo je $83 \%$ bolesnika, ostatak je bio u ambulantnim/bolničkim uvjetima. Manjina bolesnika (26\%) se prezentirala ritmom koji se ne može elektrokonvertirati, što je prediktor lošeg NRL ishoda (samo $20 \%$ ove skupine ima povoljan NRL ishod). Inicijalna hemodinamska stabilnost prediktor je dobrog ishoda (samo 11\% preživljelih zahtijevalo je incijalno inotropnu potporu, od 50\% ukupno). U $85 \%$ bolesnika zabilježene su komplikacije, najčešće infektivne prirode.

ZAKLJUČAK: Ukupno preživljenje u naših bolesnika liječenih TH bitno se ne razlikuje od nedavno objavljenih rezultata (47\% vs 50\%). I dalje ostaje otvoreno pitanje je li bitnije izbjegavanje hipertermije nakon aresta (ciljna temperatura od $36^{\circ} \mathrm{C}$ ) od samog pothlađivanja.
INTRODUCTION: Twelve years ago, two small studies on therapeutic hypothermia (TH) were published, on the basis of which guidelines were published that encourage the use of the method. ${ }^{1}$ Recently published randomized study calls into question the whole concept of hypothermia. ${ }^{2}$

PATIENTS AND METHODS: Since 2008, a total of 38 patients (14 female, 24 men), mean age 56 years (19-80) were eligible for $\mathrm{TH}$. These are patients who have survived cardiorespiratory arrest after which they remained in a coma. The aim of TH is to lower the core body temperature over 24 hours to $32-34{ }^{\circ} \mathrm{C}$ in order to improve survival and neurological (NRL) outcomes. After successful reanimation, all patients underwent brain CT, echocardiography and coronary angiography. All patients were sedated and mechanically ventilated, and invasive monitoring of central body temperature, arterial and central venous pressure was performed. Standard protocols for blood tests were used. TH was achieved by cold packs and cold saline infusions, gastric lavage, and recently by extracorporeal membrane oxygenation device and a special central venous catheters.

RESULTS: Overall survival in our group is $47 \%$, of which $42 \%$ of patients had complete neurological recovery. The initial Glasgow Coma Scale score was 3.3 (3-7). Acute coronary syndrome was the cause of arrest in $68 \%$ patients while the other dominant cause was cardiomyopathy. Out-of-hospital cardiac arrest was experienced by $83 \%$ of patients, the rest was in ambulatory/hospital setting. A minority of patients presented with unshockable rhythm which predicted poor NRL outcome (only 20\% of this group had a favorable outcome). Initial hemodynamic stability is a predictor of good outcome, only $11 \%$ of survivors required the initial inotropic support. Complications were present in $85 \%$ of patients, the most common infectious in nature.

CONCLUSIONS: Overall survival in our patients treated with $\mathrm{TH}$ does not differ from the recently published results ( $47 \%$ vs. $50 \%$ ). It is still an open question whether the avoidance of hyperthermia (aiming at $36^{\circ}$ ) is more important than TH itself.

1. Peberdy MA, Callaway CW, Neumar RW, et al. Post-cardiac arrest care: 2010 American Heart Association guidelines for cardiopulmonary resuscitation and emergency cardiovascular care. Circulation. 2010; 122:Suppl 3:S768-S786.

2. Nielsen N, Wetterslev J, CronbergT, et al. Targeted Temperature management at $33^{\circ} \mathrm{C}$ versus $36^{\circ} \mathrm{C}$ after cardiac arrest. N Engl J Med. 2013:369:2197-206. 